\title{
THE EURO AND CENTRAL EUROPE (FROM POINTS OF VIEW OF MONETARY INTEGRATION MATURITY) 1
}

\author{
TIBOR PALANKAI ${ }^{1}$ \\ ${ }^{1}$ Emeritus Professor of Corvinus University of Budapest \\ E-mail:tibor.palankai@uni-corvinus.hu
}

The paper discusses the frameworks and development of the introduction of the Euro in Central Europe, with a focus on pre-entry countries (Czechia, Hungary, Poland, Romania and Croatia). The main elements of monetary integration maturity are the state of real-integration (possibilities of large saving in transaction costs), meeting the criteria of functioning market economy and the single market; macro-economic stability and meeting the Maastricht criteria; and shortcomings of absorption (integration) capacities of the EU. Controversial questions are also discussed, such as requirements concerning inflation, the budget deficit or exchange rate stability. The paper argues that the countries under scrutiny show diverging courses of action and policies, public support is also unclear, and the interests of TNCs and political elites contradict each other. Cultural, legal, security or emotional factors will pay a key role in eventual adoption, and prospects also depend on the solution of the current debt and migration crises.

Keywords: Euro and Central Europe, monetary maturity, diverging interests, attitudes, policies, and prospects.

JEL-codes: F2, F3

\section{FRAMEWORK OF MONETARY INTEGRATION FOR THE CENTRAL AND EASTERN EUROPEAN NEW MEMBERS}

The full EU membership of CEE countries assumes their full EMU participation. This corresponds to the Copenhagen accession criteria, namely they should have the "ability to take on the obligations of membership, including adherence to the aims of political, economic and monetary union". They have no possibility of opting out, like the United Kingdom and Denmark.

As it is stated in the accession treaties, all countries will take over and implement the acquis under the chapter of economic and monetary union as from the date of their entry, while some derogation are applied: "from the date of accession, the provision of the original Treaties and acts adopted by the institutions and the European Central Bank before accession shall be binding on the new Member States and shall apply in those states under the conditions laid down in those Treaties and in this Act." (Treaty of Accession 2003, article 2.)

The immediate participation in the single market upon membership assumed by the Accession Treaties was possible, because of a pre-accession transition period, which

\footnotetext{
1 These study was supported partly in the framework of TÁMOP4.2.4.A/2-11-1-2012-0001. "National Excellence Program - Elaborating and operating an inland student and researcher personal support system." The project was subsidized by the European Union and by the European Social Fund, and partly by the BRIDGE project supported by the Jean Monnet Program. The paper was presented at the Conference on European Culture, Cluj, Romania, 29-31 October 2015.
} 
basically fell between 1995 and 2004, the date of entry. On the basis of the Commission's recommendation, at the June 1995 Cannes summit the Council approved a White Paper in which proposals were formulated for the applicant CEE countries with regard to their gradual adaptation to the 1992 program of the single internal market and their integration into it (legal harmonization, application of standards, etc.). As by 2004, most of the recommendations of the White Paper were implemented by the candidates, the immediate acceptance of the acquis communautaires concerning the single market had no obstacles.

For the old member countries the SEM's completion and the first stage of EMU overlapped. So the de facto full membership in the single market of the new members meant that they informally joined the second stage of the EMU. Parallel, they were assumed to comply with requirements of stability oriented economic policies, and start to implement their convergence programs. With that they entered into the second stage of the EMU, in fact, again right from the beginning of their EU membership. The member countries have to treat their monetary policy as a matter of common concern. It should be noted that contrary to old members, the CEE new entrants, from the first moment of their membership in the Union, will 'co-exist' with the single currency.

The joining the acquis communautaires upon entry meant that contrary to previous enlargements, there was no transition period for the CEE new members, except in some special fields, while most of the derogations were technical. The four major fields of derogations were:

- $\quad$ Free movement of labour (7 years);

- $\quad$ Selling of arable land (9 years);

- $\quad$ Direct payments under CAP postponed till 2013;

- Joining the Euro-Zone - no deadline.

While committing to the monetary integration, both the old and the new member countries were divided from the beginning how rapidly and how early should the new entrants join the euro-zone. In fact, this was the issue, which was the subject of very broad and intensive dispute. Many believed, and particularly, the old members for several reasons, that the transition period between joining the EU and entering euro-zone might last for many years, probably more than a decade. That was particularly the view of many Western experts, shared by Community officials.

The official commitments about an early and rapid euro-zone entry on the side of new members were broadly expressed. The assumptions about euro-zone entries ranged from 2006 and 2010 (basically between 4-6 years). According to the official decision of the government and the Central Bank in Hungary in 2002 the euro would be introduced in 2008. In fact, the market analysts set this date to 2008 for six new CEE members, as the most probable possibility (Világggazdaság, 11 November 2002.) In general, the central banks and the financial circles were those who forced early entry, while the governments, probably because of the constraint of the cutting budget expenditures, were less enthusiastic.

By 2015, from the 13 new members (11 from the East) 7 have introduced the euro. In fact, Slovenia (2007), Slovakia (2009), Malta and Cyprus (2008) managed to join the euro zone before the outbreak of the financial crisis. The Baltic countries have stuck to their determination in spite of the crisis. Estonia joined the euro-zone in 2011, Latvia in 2014 and Lithuania in 2015. For the other 6, the timing of euro zone joining is uncertain.

In our paper, we focus on two major issues. First, how far the five Central European countries comply with the monetary integration maturity criteria and how far they are able adjust to all of the circumstances and consequences, which follow from their participation in monetary integration. Second, we try to explain, why the Czech Republic, Hungary and Poland made a total turn concerning the euro issue, and what the main interests and positions 
behind these drastic changes are. We analyse the case of the two late comers (Croatia and Romania), who have even a chance to overtake the former three, and join the euro-zone before them.

\section{MONETARY INTEGRATION MATURITY OF CENTRAL EUROPE}

\subsection{Theoretical frameworks}

Every integration organization sets certain membership conditions or criteria for those who wish to join it. It raises the question of integration maturity of a given country or group of countries.2 It relates to several factors; level of integration and the type of the countries, which want to join the given organization.

The examination of questions of integration maturity became timely in two respects, from the 1990s. First, the question of integration maturity has arisen more and more unavoidably in connection with the increasingly close forms of integration, and the program of economic and monetary union ('positive integration') has shown that at this level, integration maturity cannot be left out of consideration. Although, market liberalization ('negative integration') is not without consequences, but they are mostly unilateral and asymmetric (the less developed, weaker partner could lose more) and the retroactive effects are not manifested in a direct manner. As the history of European integration showed, the question of unequal division of advantages was addressed either by asymmetric trade liberalization or financial transfer in favor of weaker partners (asymmetric associations).

The situation changed with economic union. The reciprocal effects are heightened and become direct. The less developed partner's economic difficulties (budget deficit or regional inequalities) have repercussions on the economy of the more developed, and can destabilize it (e.g. by triggering inflation) in more direct way. The decision to join in an economic union has fundamental effects on the institutional and political structure of the country in question. In this connection maturity or preparedness for integration is an issue that has to be examined and is a common interest.

The second reason was the aspiration for full membership of the Central and East European countries. In their case, considering the huge differences in development and the number of CEE candidates, and need of transformation from Soviet type central planning to market economy, it was clear that enlargements assume far-reaching changes before entering the Union.

Under these conditions, in the early 1990s, the EU had to set two types of accession criteria, which assumed a certain level of integration maturity in the given context. In 1991, the Maastricht criteria formulated the basic stability conditions for joining EMU. In 1993, the Copenhagen criteria set the requirements for EU membership for CEE candidates. The Copenhagen Criteria were in practice attempting to formulate a certain desirable minimum transformation for these countries, while it already referred to the requirement of participation in the single market.

In relation to the monetary integration the following basic criteria of integration maturity were formulated as:

1. Achievement of a certain state of integration of real-economy (integratedness).

2. Market economy ("functioning"), inclusion into the single market.

3. Macro-stability and stabilization (most of all meeting the Maastricht convergence criteria).

4. Integration (absorption) capacities of the Union.

\footnotetext{
2 The question of integration maturity was analyzed by a research group of the Department of World Economy at Corvinus University of Budapest, and in a program financed by the Hungarian National Research and Development Plan between 2002-2004 (see Palankai 2004; 2005).
} 
We have to emphasize that fulfilment of these maturity criteria is not only a precondition of integration but also the only way in which the advantages of integration outweigh its costs. This is the way in which integration serves their interests, and it is an expression of integration maturity.

\subsection{State of monetary integration maturity of East Central European countries 2.2.1. State of real-integratedness}

The creation of a single currency assumes a certain state and level of integration of the given organisation. No question that in absence of a minimum level of relations, a common currency is hardly imaginable. In this context, the level of integration is conceived in terms of intensity of relations, interconnectedness and interdependence (integratedness). It would be hard to define what the exact level should be, but it is clear that it should be high enough in terms of transaction costs. Only a sufficiently high level of integration can offer savings in transaction cost. As the analyses on the Euro showed, in the EU by the 1990s, as result of the creation of single market, transaction costs were substantial. The introduction of the Euro was an important factor in increasing competitiveness of the EU companies and countries. In fact, the collapse of the Euro would be a fatal blow to the competitiveness of the EU and would lead to the marginalisation of continent.

Real-integration can be measured by a great number of indices and parameters. We use only few of them, but they largely represent and indicate where the real integration processes stand and how they developed in the last decades. We analyse and measure realintegration by intensity of relations (trade or factors), interdependence, interconnectedness and transnationalisation of company sector.

1. Share of export and import to GDP, which can be related to total trade $(T X t / Y \times 100$ or $T M t / Y \times 100$, where TXt is total export and TMt the total import), or to intra-regional trade $(T X i / Y \times 100$ or $T M i / Y \times 100$, where TXi refers to the intra-regional export and TMi to import). The former indicates the intensity of global integration (integratedness), while the latter is a demonstration of the intensity of regional trade integration. The annual data and their change express the intensity and integratedness, i.e., the state and the dynamics of the integration process. The indices, besides intensities, also indicate openness and dependencies. The higher the indices, the greater the country's openness and its dependence on external factors and processes.

The about 5 decades of European integration has shown a very rapid intensification of trade relations. The trade of the EC/EU (both total and internal) has expanded rapidly, and the growth of the total export of goods and services was around twice as rapid than that of GDP. Due to these processes, the intensity of trade relations expanded substantially, and in half a century, and it increased from a low (nearly 20\%) to a high level (more than $40 \%$ ). The same happened in terms of the internal trade, its share in GDP from about $8 \%$ trebled to nearly $25 \%$; and the structural openness, particularly for some smaller countries, reached a particularly high level (Eurosat 2014).

In the past 50 years, the economy of the member states has strongly internationalised. This is a new quality, which is none other than integration.

The intensity of the trade integration (goods and services) of EU members shows plenty of differences and extremities. There are extremely high intensity countries with above $80 \%$ trade share in GDP (LU, BE, SK, HU, and ML), while Greece is close to the low intensity $(22 \%)$, and in terms of goods it is in the no intensity $(8 \%)$ band, and in this respect the same is with Cyprus. In some sense, this is some of the dimensions of peculiarities of Greek membership in the Euro-zone. There is no rule that the same level of integratedness is required for a monetary integration, but the great extremities can create tensions. 
In general, the developed small countries have high or very high intensity of external economic relations and high openness of their economies, both in term of their regional and global integration. This is supported by the different attempts of measuring integration (Globalisation or Interconnectedness Indices), and beyond the EU members, we can mention such countries as Switzerland, Norway or Singapore. It should be noted that besides the Benelux and the Scandinavian countries in spite of their somewhat lower level of development (per capita GDP), most of East-Central Europe and the Baltic countries belong to this very high intensity group. Some countries owe this status to their service economies (Luxemburg, Malta, Cyprus) as in terms of their goods export, they have more modest qualification. The same applies to Greece. Besides the developed large countries (except Germany), the Mediterranean EU members fall into the moderately low intensity group, with their 22-34\% GDP-trade shares.

2. Share of regional trade to total $(T X i / T X t \times 100$ orTM/TMt $\times 100)$. It indicates the interconnectedness and regional concentration of the relations in the integration organisation.

The strengthening of integration relations has meant an increase of the share of intratrade among the member countries. The growth of cooperation, however, was not proportional, as the process was characterised with sub-regional concentration, particularly among the neighbouring countries. This is a general characteristic of European integration, and the process was further strengthened by the various enlargements.

When measuring sub-regional concentrations or connectedness, we can depart from the proportions of external and internal trade. These proportions for the whole Union are roughly $67-33 \%$, as far as internal and external trade are concerned, and can be used as a basis of comparison.

EU internal trade is highly concentrated sub-regionally. The Western European EU members, besides the high intensity of their trade, are characterised by a high level of connectedness (which is above 67\%) as well. In the case of Belgium and Ireland, about 85$86 \%$ of their intra-export goes to the sub-regional partners, but this proportion is close to $65 \%$ in case of the UK. About $75 \%$ of the intra-trade takes place within the Western European core countries.

Inside the core, Germany is a central and strategic partner. On average, $23.2 \%$ of the EU total trade is provided by Germany. The two extremes in this respect are Estonia with $8.8 \%$ and Austria with $43.1 \%$ of the German share. In spite of the high German participation, the countries of the region are also strategic partners of Germany, as their share is above $10 \%$ in the export trade of Germany. In terms of internal export, this is the case with France, Italy, The Netherlands and the UK, with Belgium and Austria close to this position. Consequently, despite of the German preponderance, the core countries' relations are characterised by relatively balanced interdependence.

The other main region that is highly connected with the Western European Center is East Central Europe. In fact, East-Central Europe is connected to the West largely through West-Central Europe (Austria, Germany and Italy), and this connectedness of Central Europe in total is quite high. East Central Europe is particularly closely connected to Germany (accounting for around a third of the trade relations). Beyond that, the relations are balanced in the region and there are no unilateral dependences. The only exceptions are the CzechSlovak relations, and the strategic dependence of Slovenia on Austria, France and Italy. In a similar vein, Central Europe is also a strategic partner for Austria (20\%) and Italy (11\%).

Germany is the number one partner for 21 countries. It is number two for Cyprus, Lithuania, Portugal and Spain, and comes as third for Latvia (12\%) and fourth for Estonia $(8.8 \%)$. 
The intensity of interconnectedness can be measured by confronting shares of trade and population. For the different sub-regions, their share in internal trade and total population is compared: $X i a / X t \times 100 / \mathrm{Pa} / \mathrm{Pt} \times 100(\mathrm{Xi}$-internal export; $\mathrm{P}$ - population, and "a" stands for the country or the region). The quotient of the two indicates the interconnectedness of the region by filtering out the differences that arise from the size of the regions. However, differences arising from the levels of development remain (Table 1).

Table 1. Intensity of interconnectedness for internal export in the main sub-regions of the EU in 2009

\begin{tabular}{|c|c|c|c|}
\hline Region & $\begin{array}{c}\text { Share of export in EU } \\
\text { total in \% }\end{array}$ & $\begin{array}{c}\text { Share of } \\
\text { population in } \\
\text { total in \%- }\end{array}$ & $\begin{array}{c}\text { Interconnectedness } \\
\text { Quotient }\end{array}$ \\
\hline EU27 & 100 & 100 & 1 \\
\hline Western Europe & 74.8 & 60.1 & 1.25 \\
\hline Northern EU & 6.0 & 5.0 & 1.20 \\
\hline East Central EU & 10.5 & 10.3 & 1.02 \\
\hline Baltic members & 0.7 & 0.8 & 0.93 \\
\hline Southern EU & 6.6 & 13.8 & 0.47 \\
\hline Latin EU* & 23.9 & 36.2 & 0.66 \\
\hline
\end{tabular}

* FR, IT, ES, PT.

Source: Eurostat (2011).

The data in Table 1 reflect the minimally above average interconnectedness of East-Central Europe. If we take into account the differences in the levels of development, this interconnectedness is intensive as compared to Western Europe and Scandinavia. The low interconnectedness of the Southern EU is striking. The picture does not change if we consider only "Latin" countries of the sub-region.

As the sub-regional trade relations indicate, the distance or the geographic closeness of the countries do count. This is further strengthened by traditions, historic ties, or cultural or linguistic similarities.

In general, European integration does not represent a monolithic economic bloc; it is structured by sub-regional concentrations in which Germany plays a dominant connecting role. East Central European integration to the West-European means close connection to the Euro-zone.

3. The share of capital import $(C M / Y \times 100)$ and export $(C X / Y \times 100)$ to $G D P$ and to each other $(C X / C M \times 100)$ indicate the intensity of capital relations. In our present analysis, concerning factor integration we concentrate on capital movements while that of labour force is left out.

In terms of capital import (to GDP), Belgium (200\%), Ireland (111\%), Sweden, Estonia and The Netherlands (above 80\%), and Hungary (78\%), Czech Republic (64\%), Slovakia(60\%) and Bulgaria(63\%) are characterised by a very high intensity. The high Central European proportions are the results of massive investments in the region. In the case of The Netherlands, what is reflected is the traditional foreign investor role. The foreign investments are highly intensive in the UK, Denmark, Portugal, Austria. Spain and Poland. Only Italy (17\%) and Greece (13\%) can be considered as the low intensity category. The low level of Greece's global and European integration is also expressed in these respects (OECD 2012). 
Besides high intensities, the most developed countries are characterized with net external investment positions. In most of these countries, the capital export is about a third higher than the stock of received capital.

In the last decade, there has been a start of capital export with regard to the new Eastern members. The pioneers in this process are Slovenia, Hungary and Estonia. In the case of Hungary, if the ca. $€ 15$ bn investments abroad are compared with the $€ 80$ bn FDI in the country, the rate is only about $20 \%$. In the case of the other countries, these investments have only just started, and they are typically around or below $10 \%$ per cent in relation to the FDI in the country.

This is a reflection of the asymmetry of their integration. "Capital export is closely related to the level of development, and in the case of an expanding economy, the increase of this activity is a necessity. At the same time, there is no rule to regulate how the level of development and capital export should be related to one another. Therefore, in absolute terms, it cannot be determined whether Hungary is ahead or behind the 'average'. This is dependent on the level of development of geographically close countries (as they are more attractive as a terrain of potential investment) and their capital absorption capacity." (Világgazdaság, 30 June 2004)

4. From the 1970s onwards, the start of the capital export of European companies was accompanied by their growing transnationalisation. The EU has become one of the main areas of global integration, in which process European TNCs have played a leading role. From the 1980s, this was strengthened by rapid integration and the transnationalisation of international financial markets. Accordingly, the economies of the core EU countries have become highly transnationalised, both in terms of their positions in the national economies, and in the expansion and competitiveness of the global economy.

In relation to TNCs, it is generally agreed that transnational networks is a more suitable term. Transnational networks are large groups of small and medium sized enterprises, which cover research and development, production, financing and various different services.

Hungary and the new Eastern EU members, as result of the high intensity of their capital integration, are parts of this transnationalisation process. This is, however, largely one-sided and asymmetric based on the domination of foreign investors. The one-sidedness has started to dissolve, but the new Eastern EU members still have a long way to go in the process. In the last few years, several Hungarian (and other Central European) companies (MOL, OTP Bank, Trigranit, Telekom, Fornetti, etc.) have aspired for a transnational status and have applied such strategies and positions. Their expansion, however, is mostly limited to the neighbouring countries.

Asymmetries are particularly characteristic of transnational networking. Moreover, the absence of established "national" TNCs is accompanied with the low participation of local SMEs in the global integration processes. This is particularly striking in comparison to the core countries.

In spite of differences, the EU belongs to the most highly integrated regions of the global economy. This is a strong basis for its monetary integration. In the EU, by the 1990s, the real-economic conditions for monetary integration had been created.

In the last 20 years, the Central European economies have become one of the most open and integrated economies in the world economy. About $90 \%$ of their trade is conducted in liberalised frameworks, and their economy is fully exposed to global competition. That is a favourable condition for their monetary integration. In terms of real integration, the Central European countries have the potentials to exploit the advantages of that monetary integration.

\subsection{From functioning market economy to single market}


The monetary union followed logically from the program for a single European market. Complete liberalization of the capital markets threatened the effectiveness of national monetary policies, and the only possible way of "escaping forwards" was the creation of a single currency. "The economic advantages of 1992 are certainly not fully achievable without a single currency, especially in the field of financial market integration. In addition the EMS in its present stage of development may not be compatible with complete capital market liberalization as required by 1992" (European Commission 1990: 17-18). According to Padoa-Schioppa, the single market tries to undertake an impossible task, that of reconciling the four priorities of economic policy, namely free trade, completely free movement of capital, fixed exchange rates and national autonomy in following monetary policy. "These four elements form what I call an 'inconsistent quartet': economic theory and historical experience have repeatedly shown that these four elements cannot coexist, and that at least one has to give way"(Padoa-Schioppa 1989: 373). Thus, in the interest of the normal functioning of the single market, monetary integration, or EU-level centralization of monetary policy, is required. This is achieved with the EMU. Monetary union is supported by the broad integration of national markets.

As monetary integration was concerned, it was clear from the beginning that the different countries were not equally prepared, and that meant a certain risk for the future stability and satisfactory operation of the project. There were substantial differences in the interests among the countries. It is not surprising that so far the euro has been introduced only in 19 countries, while participation of further countries is delayed by either formal opting out agreements, or by different types of policy choices, which put their joining into the uncertain future. The same applies to some of the reform packages, particularly those which were brought for improving the governance of the euro-zone. In these context, we should speak about "multi-speed" or "variable geometry" Europe.

A normally functioning market economy is a starting condition in relation to every form of integration. The whole theoretical and analytical system of integration economics is based on this assumption. Only with the proper functioning of market mechanisms can the advantages of internal free trade be exploited. In some sense, the question, as far as the factor markets are concerned (flexibility of prices and movements) are closely related to the requirements of the optimum currency area.

We know there is no such thing as a "perfectly" functioning market. It is no accident that the customs union and common market were accompanied from the outset by stringent supervision and regulation of competition, and internally competition policy had to be raised also to community level, this being associated later with wide-ranging legal harmonization to ensure freedom and equality in trade. Thus to achieve a "functioning market economy" many measures were applied. The 1992 program of the single European market sought to systematically eliminate all the real obstacles in the way of the "four freedoms", and ultimately extend the conditions for a really "functioning market economy".

As result of broad and complex transformation of their economies, the CE countries achieved the status of "functioning market" by the end of 1990s (Hungary in 1999). This meant that by acquiring full membership in 2004, they fulfilled that Copenhagen criterion. In case of the later comers (Bulgaria, Croatia and Romania) these were implemented later, and the single market regulations were introduced with the EU entry.

Concerning the EMU, the question marks which arose were about the derogations concerning the 7 year transition period with regard to free movement of labour (with the similar 9 year delay in acquisition of arable land in the CEE candidate countries by foreigners). Of course, one can argue that really it is the free movement of capital that counts mostly from the point of view of the smooth functioning of the EMU, and that was fulfilled. Although labour mobility is considered important by the theories of the optimum currency 
area in terms of avoiding aggravation of regional differences, from the point of view of the CEE countries' joining the euro-zone these were not exclusive limitations. In reality, only Austria and Germany insisted on limiting the free movement of labour, while most of the others with some delays and exceptions opened their labour markets. Later the movement of people from the East to the West proved that the formal derogations had no significant limiting impacts in this respect. From this point of view the question of arable land was a marginal issue.

The high level of real-integratedness and the single market are the two legs of monetary integration, and any single currency cannot be created without them. By the 1990s, these conditions were secured for the EU. For the CEE new members, the same applies by their EU entry as well.

\subsection{Macro-economic stability and meeting convergence criteria}

Economic stability is an important factor in integration maturity from the point of view of the normal functioning of the market, and consequently from the point of view of the ability to exploit the advantages of any market integration.

Macro-economic stability and integration are mutually dependent, therefore while it is one of the preconditions of successful integration, at the same time it is also an indicator of the success of that integration. There have been lengthy, chicken-and-egg discussions about the performance of the economies of the EC countries, particularly in the 1960s, when no one could decide which was more important: rapid economic growth promoting smooth and rapid trade integration, or dynamic intra-trade, which was then supposedly one of the main factors in rapid economic growth.

The collapse of Soviet systems was accompanied by "transformation crisis". It meant deep recession (between 1989 and 1993, a drop of GDP between 20-40\%), most countries suffered hyper inflation (more than three digits, except Hungary and Czechoslovakia), unemployment jumping above $10 \%$ (formerly non existent in most of the countries), and the deterioration of budget balances. The countries by late 1990s and early 2000s consolidated their economies.

In fact, by the time of gaining full EU membership, most of the Eastern countries got relatively close to meeting the Maastricht criteria (see Table 2), and the fulfilment of these in a relatively short time largely depended on the countries' political will and determination. Hungary was close to meeting the Maastricht criteria in 2001, and the deadlines for euro zone membership were realistic. The stabilisation policies, however, which would have been necessary anyway, did not happen, and the possibilities of euro-zone membership faded away. Instead, by 2006, the country got into a serious crisis. Beyond contractual obligations, most of the analyses agree that the introduction of the euro corresponded with the national interests.

Table 2. State of fulfilment of the convergence criteria in the 11 new EU members, $2002-2014^{*}$

\begin{tabular}{|l|l|l|l|l|l|}
\multirow{3}{*}{ Country } & Year & Inflation (\%) & $\begin{array}{l}\text { Budget deficit } \\
\text { (\% of GDP) }\end{array}$ & $\begin{array}{l}\text { Public debt } \\
(\% \text { of GDP) }\end{array}$ & $\begin{array}{l}\text { Interest rate } \\
\text { (nominal) }\end{array}$ \\
\hline \multirow{3}{*}{ Czech Republic } & 2002 & 1.4 & -6.8 & 28.8 & 4.9 \\
\cline { 2 - 6 } & 2008 & 6.3 & -2.7 & 30.0 & 4.6 \\
\cline { 2 - 6 } & 2014 & 0.9 & -1.9 & 45.8 & 2.2 \\
\hline \multirow{3}{*}{ Hungary } & 2002 & 5.2 & -9.2 & 57.2 & 7.1 \\
\cline { 2 - 6 } & 2008 & 6.0 & -3.8 & 72.9 & 8.2 \\
\cline { 2 - 6 } & 2014 & 1.0 & -2.9 & 79.5 & 5.8 \\
\hline Poland & 2002 & 1.9 & -3.6 & 41.1 & 7.4 \\
\hline
\end{tabular}




\begin{tabular}{|c|c|c|c|c|c|}
\hline & 2008 & 4.2 & -3.7 & 47.2 & 6.1 \\
\hline & 2014 & 0.6 & -2.9 & 49.2 & 4. \\
\hline \multirow{3}{*}{ Slovakia } & 2002 & 2.0 & -5.7 & 43.3 & 5.3 \\
\hline & 2008 & 3.9 & -2.4 & 28.2 & 4.7 \\
\hline & 2014 & 1.5 & -2.6 & 55.4 & 3.2 \\
\hline \multirow{3}{*}{ Slovenia } & 2002 & 7.5 & -2.4 & 29.5. & 6.4 \\
\hline & 2008 & 5.5 & -1.8 & 21.6 & 4.6 \\
\hline & 2014 & 1.9 & -14.6 & 78.1 & 5.8 \\
\hline \multirow{3}{*}{ Latvia } & 2002 & 2.0 & -2.7 & 14.1 & 5.4 \\
\hline & 2008 & 13.3 & -4.1 & 19.5 & 6.4 \\
\hline & 2014 & 0.0 & -0.9 & 38.2 & 3.3 \\
\hline \multirow{3}{*}{ Lithuania } & 2002 & 0.4 & -1.5 & 22.4 & 6.1 \\
\hline & 2008 & 11.1 & -3.3 & 15.6 & 5.6 \\
\hline & 2014 & 1.2 & -2.6 & 39.0 & 3.8 \\
\hline \multirow{3}{*}{ Estonia } & 2002 & 3.6 & -1.4 & 5.3 & 4.3 \\
\hline & 2008 & 10.6 & -2.7 & 4.6 & 4.0 \\
\hline & 2014 & 3.2 & -0.5 & 10.1 & 0.75 \\
\hline \multirow{3}{*}{ Croatia } & 2002 & 2.1 & -5.1 & 38.3 & 6.25 \\
\hline & 2008 & 5.8 & -2.7 & 36.0 & 6.0 \\
\hline & 2014 & 1.1 & -3.8 & 67.1 & 4.8 \\
\hline \multirow{3}{*}{ Bulgaria } & 2002 & 6.1 & 1.8 & 36.1 & 5.4 \\
\hline & 2008 & 12.0 & 1.8 & 14.1 & 5.4 \\
\hline & 2014 & -0.8 & -1.5 & 23.13 & 3.5 \\
\hline \multirow{3}{*}{ Romania } & 2002 & 11.9 & -1.2 & 18.6 & 4.0 \\
\hline & 2008 & 7.9 & -5.4 & 13.3 & 7.7 \\
\hline & 2014 & 2.1 & -2.2 & 40.1 & 5.3 \\
\hline \multirow{3}{*}{ Eurozone } & 2002 & 2.2 & -3.1 & 69.1 & 2.0 \\
\hline & 2008 & 3.3 & -0.6 & 66.2 & 4.0 \\
\hline & 2014 & 1.4 & -2.9 & 92.1 & 0.75 \\
\hline
\end{tabular}

Source: ECB (2004; 2010); European Commission (2014) and Eurostat.

The candidates had no problem with public debt, and with the exception of Hungary, they were far below the $60 \%$ reference value. The average debt level of the new CEE members was around $32 \%$ of their GDP (in case of Hungary $57 \%$ ), which was much lower than it was in the case with most of the first euro-zone members before their joining. Concerning budget deficits and inflation their performance was much more varying, Hungary, the Czech Republic, Slovakia and Poland had relatively high budget deficits and had to make serious efforts to comply. (In 2002, Hungary had an extremely high budget deficit, which was close to $10 \%$, but by 2003 it was brought down to $4.8 \%$.) In terms of inflation, only Hungary and Slovenia were high above the euro-zone averages (and Estonia only slightly).

The financial crisis brought substantial deterioration in macro-performance. In 2009, there was an unprecedented fall of production in the EU, with an average 5.6\% drop of GDP in one year in the 27 countries. However, the recession of the Western and the Southern EU members has been more moderate, and only Ireland (5.5\% contraction) was close to the average. The only exception was Finland, with an $8.5 \%$ recession. At the same time, a dramatic loss of production was experienced in the Baltic countries (14-18\%), and it was above average in Slovenia, Hungary and Romania. In 2009, out of the 27 members, only Poland was able to achieve a positive economic growth (1.6\%). 
The global financial crisis brought dramatic changes in the budgetary situation of the EU members. By 2009, the average budgetary deficit of the EU jumped from the $1.8 \%$ level of 2004 to $6.7 \%$ (for the Euro-zone this was 6.3\%). Compared to 2004, the budget balance worsened in every country except Germany, Austria and Malta, and in some countries it went above $10 \%$. The budget deficit of Greece doubled at $15.6 \%$, but record deficits were also produced by Ireland (13.9\%), the U. K. (11.5\%), Spain (11.2\%) and Portugal (10.2\%). With regard to the new members, in 2009 the deficit of Latvia $(9.8 \%)$, Lithuania $(9.4 \%)$ and Romania (9\%) got close to ten per cent, but Poland $(7.4 \%)$ and Slovakia $(8 \%)$ were also above the average. The deficit of Hungary was only $4.6 \%$, but due to its own crisis, a record deficit $(9.2 \%)$ was produced in 2006.

As a consequence of the crisis, between 2009 and 2014, the public debt of all the countries increased, and such euro-zone members as Greece, Italy, Portugal, Ireland (above $120-170 \%$ debt levels) or Spain got into a serious sovereign debt crisis. In 2008, the eurozone public debt was $66 \%$, which jumped to $85 \%$ by 2009 , and it further accelerated to $92 \%$ by 2014. In 2014, out of the Euro-zone members only Luxembourg and Finland, and the new Eastern members (except Hungary, Slovenia and Croatia) were bellow the $60 \%$ ceiling.

In spite of several improvements, the crisis is not yet over. This particularly applies to the debt and the growth crisis, and the solution of the Greek crisis remains uncertain. Grexit cannot be excluded, and it would have far reaching consequences for the whole monetary union. The migration crisis creates new political tensions among the EU members, and the European integration arrived to a cross road.

In spite all of this, by 2014, the six CEE eurozone candidates consolidated their economies, and they got close again to fulfilling the Maastricht criteria. As far as the main criteria are concerned, they correspond to Maastricht, and their compliance rather calls for legal and policy decisions. All need legislation in terms of harmonizing their Central Bank independence with TFEU and their integration into the ESCB. None of them are in the ERM2, but exchange rate stabilization rather depends on external factors and policy decisions. In case of Bulgaria, the currency board means stricter stability conditions, than the ERM. The same applies to official exchange rates. The inflation is in all cases below the $1.7 \%$ reference value, and in case of Romania is very close to it $(2.1 \%)$. The budget deficit, with the exception of Croatia (3.8\%), is below 3\% of GDP, and the debt levels are between $40-50 \%$ of GDP. On the one extreme is Bulgaria with its $23 \%$, and on the other Croatia with $67 \%$ and Hungary with $79 \%$ debt levels. Both countries could be able to produce a declining rate of their indebtedness.

Among the new Eastern members, the joining of the euro-zone or staying out can not be explained by any "objective" conditions or factors (level of development or macroeconomic performance), which would have determined the decisions of the given countries. Slovakia was not better positioned or had any particular factor which could explain why the country joined the euro-zone on the one hand, and why Hungary or Czech Republic have abstained from this step on the other. On the contrary, in many respects, the prospects and possibilities of the latter two countries were better than that of Slovakia. The same applies to the comparison of Poland or the Baltic countries. The decisions were politically motivated and depended on political will and determination of the country. In 2001 or 2002, the chances of Hungary joining the Eurozone were not worse than that of Slovakia, the difference was rather in perceptions of the future and the expected consequences. In fact, the success or the failure of the euro-zone members were primarily determined by the adjustment policies of the given countries.

\subsection{Integration (absorption) capacities of the Union}


The question of absorption or integration capacities first arose in relation to the Eastern enlargements. The Copenhagen accession criteria, in 1993, besides the requirements towards the candidates, refer to "The Union's capacity to absorb new members." The question was not clearly specified, and besides the budgetary implications, nothing else was concretely indicated. The problem was demonstrated by the Agenda 2000, where the financial resources allocated to the new members were already planned. As the later developments of the enlargement process proved, attention was only devoted to the minimum levels of meeting the accession criteria, but the majority of questions of joining (particularly the timing) were decided primarily on political grounds. Although the maturity considerations were followed, they played only secondary role.

The euro was born from high real integratedness and the single market, but in its shaping and timing, the political factors also played an important role. Beyond strictly requiring the fulfillment of the Maastricht (monetary and fiscal) convergence criteria, the broader considerations of maturity were missing. How far these countries can be considered an optimal currency area formally was not examined. Certain deficiencies in integration maturity were neglected, and that particularly applied to the large differences among the new euro members. The institutional set up of the EMU was shaped on political grounds (minimizing the need for giving up sovereignty), and the necessary absorption capacities were poorly secured. The problems were demonstrated both in conceptual and constructional deficiencies of the monetary union project.

a) The economic and monetary union created a new governance structure (multi-level), where all the levels (union, national, local, or even companies, organizations, or banks) had to adjust and their consistent cooperation and had to be secured in all dimensions. The euro construction, in this respect, was far not adequate, it had many deficiencies, and later during the crisis, they lead to disastrous consequences. The Economist rightly compared the euro zone to a boat, which "was fit only for fair-weather sailing, with an anarchic crew and no life boat." (The Economist, 26 November 2011)

b) The single currency called for common monetary policies, but the budgets remained in national competences. The Stability and Growth Pact set the frameworks and rules of national budgetary policies, but they were incomplete, indicatory and lacking strong enforcement mechanisms.

c) The mechanisms of "automatic stabilizers", characteristic for the classical monetary unions based on federal political structures, were totally lacking. The EU budget is far from meeting of requirements of a federal budget. In facts parallel with the creation of monetary union, instead of increasing its role, its resources were rather cut back. The role of structural funds was increased, but they were not enough to fulfill the correcting and compensation requirements related to social and regional disparities created by the monetary integration.

d) In order to enforce tough discipline on the members, the no bail out rule was an important message for responsible policy behaviors. Later, under the circumstances of the global financial crisis, it proved to be unattainable and threatened with the collapse of the whole monetary union.

e) The focus was on monetary and fiscal policies, while the financial markets banking sector) were left out of attention.

f) One of the main deficits were related to adequate national policies (policy mixes), which failed to adjust to the new conditions and requirements (proper income or structural policies among others). Instead of adaptations, some governments rather used the possibilities of free riding (using new cheap money for buying political popularity or votes), but the irresponsible behavior characterized the banks or individual investors (real estate bubble) as well. 
g) Misunderstanding and over estimating the regulatory role of the market. The euro project was born in the atmosphere of ultra-liberalism of the 1990s, which expected a regulatory and disciplining role from the market. As it later turned out, the markets rather encouraged irresponsible behaviors and instead of disciplining in advance, rather punished afterwards, in fact very strictly.

As result of all of these, the institutional and policy frameworks were unable to properly absorb the members and answer the later challenges. Clearly, the EU could not exempt itself from the global financial crisis, but the deficiencies of the euro's construction aggravated the situation, and resulted in a serious crisis of the single currency. It was not a classical currency crisis (inflation or devaluation), but rather a sovereign debt crisis of certain members, but it lead even the questioning of the mere existence of the whole system. We still do not know how the falling out of a member (Grexit) would affect the fate of the whole eurozone.

The deficiency of policy and institutional frameworks can be raised also in terms of accommodation of the new members into the EMU. While the setting of Maastricht criteria with aim of achieving sustainable monetary and fiscal stability was an important decision, , one can raise several questions about their relevance to the new CEE members. We abstain from discussing it in detail, as there is a large literature on the issue, but we raise three questions, which affect the meeting of the Maastricht criteria and the EMU membership of the Central European countries.

- $\quad$ The major criterion of Maastricht in terms of monetary stability is in fact a direct targeting of inflation. The main aim of price stability, among others is primarily related to maintaining competitiveness of the member countries. There is an absolute target of the European Central Bank, which set a ceiling of price increases in $2 \%$, and while it tolerates them up to $3 \%$ (reality of years before the financial crisis), it corresponds to the upper limits of "desirable inflation". In case of Maastricht this ceiling seems to be relative, setting the average of the three "best performing" countries as a benchmark. It is true that it lets a $1.5 \%$ upward deviation, but still in absolute terms, the target could be deflationary. And that could be particularly the case with the new Eastern member. A $2 \%$ price increase can be problematic, if the growth of productivity is less than $1 \%$. But even $3 \%$ inflation could cause no problems if the productivity increase is around 4\% (or even more), as it was the case with the most of new Eastern members following the mid 1990s, up to the financial crisis. This targeted price rigidity may contradict to the interest of emerging countries with long road to convergence.

The same applies to the limits sets on budgetary deficits. The Maastricht 3\% deficit is a realistic target. But the frameworks set by the Fiscal Compact through assuming a balanced budget, are more problematic. According to the historical experiences, the catching up countries usually required budget deficits for financing their modernisation. As the accumulated debt finances the creation of competitive capacities, it does not cause any problem. It was, of course, a different case, when the credits were mostly used for financing consumption of mistaken modernisation projects, as it happened in the 1980s with Hungary or Poland. The Central European countries are in the process of their convergence, and this can last for decades. The frameworks of the Fiscal Compact contradict their interests.

- The Maastricht criteria assume the candidates countries to be in ERM for at least two years as a condition of entry into the euro zone. As historical experiences suggest, the exchange rate bands can be tempting from points of view of speculation. The most dramatic example was the UK in 1992, when the wrongly set band proved effective in provoking an attack against the pound, and in which case even the $+/-6 \%$ proved to be too narrow. It was not by chance that the bands in ERM1 were broadened to $+/-15 \%$ in 1993 . 
Hungary had an ERM2 imitation from $2001(+/-15 \%)$, but gave it up in 2008, due to the speculative threats of the financial crisis. Among others, the three Central European countries float the rate of their currencies due to this reason. Therefore, many feel totally relevant and supportable the proposal of the Polish finance minister, which raises the possibility of abolishment of the ERM2 participation requirement in favour of exchange rate stability without band limitations. "Some policy makers have even said they believe that in Poland's case the requirement that the zloty enter ERM-2 for two yours before entry, could be wavered." "Policy makers and economists have long said that entering the euro zone's preadoption currency corridor would be risky for Poland because it would encourage speculation in the highly liquid zloty, and could push up prices of consumer goods." (Reuters, 4 June 2014.)

Originally there were fears on the old members' side, including the main institutions (Commission, ECB or the European Parliament), that the accession of the new Eastern members into the euro project may undermine the stability of the whole system. The five new euro members from the Eastern region so far have not proved that expectation. Steps were for rather stiffening the conditions, and the acceptance and recognition of the special needs of these countries was practically lacking. Meeting the requirement of Maastricht is acceptable for these countries, and the problems are related to the whole euro-zone.

\section{ADJUSTMENT AND ACCEPTANCE OF EURO - INTERESTS AND POLICIES}

\subsection{Uncertain prospects}

The CEE new members, concerning the monetary integration, took different course of policies and actions. While all of them accepted to contractual obligations concerning the EMU, as far as adoption of the euro, they show great differences. Although each of them have their own interests, attitude or policies, we can put them roughly into three main groups.

1. There are five countries (the Baltic countries, Slovenia and Slovakia), who joined the euro-zone up to 2015 and fully adapted the monetary policy part of the EU treaties. The majority of their population supports euro-zone membership and they fully participate in the Euro Group.

2. The three Central European countries of the Visegrad Four (Czech Republic, Hungary and Poland) take a hesitant position, they are highly critical about the euro project, and they have no definitely set deadline for joining. Their population has a contradictory attitudes towards the euro. In Hungary, although the number of rejecters increased, according to a 2012 poll, the pro and con views were more or less in balance. On the other hand, in Czech Republic and in Poland the majority of the population were against euro zone entry. As it is noted in a survey: "In 2012, support for the single currency has steeply declined over the five year period, between 2007-2012, where it once represented a majority." By 2012, only $50 \%$ of Hungarians supported the euro, while $42 \%$ were against. In the other two countries the opinions were more negative, in Poland only $36 \%$ supported and $56 \%$ were against, and in Czech Republic 22\% supported and 74\% was against. The three countries with the highest fall of support were the Czech Republic (38 points) Denmark (24 points) and Poland (18 points) (Notre Europe 2012: 22). For 2015, the Eurobarometer polls, particularly for Hungary show somewhat different pictures (the two are not comparable) In April of 2015, 60\% of Hungarians were in favour, and 35\% against the euro, in Poland $44 \%$ in favour, $53 \%$ against, while in Czech Republic only $29 \%$ in favour and $70 \%$ against (Eurobarometer 2015).

3. The three later comers (Bulgaria, Romania and Croatia) are more positive about joining the euro zone, the majority of their public opinion (except in Croatia) is for the euro. In April of 2015, the Romanian government declared that it is still committed to its target for euro adoption in 2019, and able to comply with all nominal convergence criteria. Bulgaria and 
Croatia do not have an official target date for introducing the euro. There are preparations, but references are made about waiting till the euro crisis is over.

The euro enjoys very high support in Romania. In April 2015, 68\% of Romanians supported the euro, and only $26 \%$ were against. The same data for Croatia was $53 \%$ in favour and $40 \%$ against, while for Bulgaria 55\% for and $40 \%$ against (Eurobarometer 2015).

As so far the political will and determination played primary role, the three later comers have chance to be the next entrants of the euro project. The ongoing financial and migration crisis, however, may delay their euro adoptions, despite the fact that they are close to meeting the Maastricht criteria.

\subsection{Influencing factors}

Euro-zone accession can be motivated and influenced by several political, legal, social, cultural or even emotional factors. We analyse the political and social aspects through changes in the interest and position of professional, business and political elite, and the role of the media. Legal problems can also arise. When a country decides about euro zone participation geopolitical, security or sovereignty considerations can also have an impact.

The big differences among the countries can be explained by different factors, and in these respects, the domestic political situations and scenes play an important role. In the all analysed countries, most of the parties are not against euro adoption, although they attach different importance to it. Seemingly, the parties and politicians are concerned rather with their short term political interests, and if the euro preparation would mean unpopular stabilisation measures, they rather refrain from the issue. That was particularly the case with Hungary after 2002, when the chances of euro adoption by the projected time (end of the decade) were missed. As, in fact, it is rightly noted on Hungary: "Politicians who were mainly seeking domestic political gains (in terms of attracting voters through pledges to enhance voter income) were not at all focused on taking the necessary steps that will lead eventually to euro adoption" (Dandashly - Verdun 2009: 12). That remained characteristic to all parties and for all election campaigns. And we can state that it was so in the other countries as well.

The opponents of the euro are of rather extreme right or left wing parties. In Hungary, the Jobbik, in Czech Republic the Communists, and in Poland the Law and Justice Party (PIS), which have strong reservations, particularly against rapid joining. In most cases, the opponents are not organised along party lines. Although they are not in majority, with the exception of PIS, they could be strong enough to influence the attitudes of the governments.

Persons can play an important role too. In the Czech Republic, while Václav Havel was in favour, Václav Klaus took a euro-sceptic position. They were both influential towards political parties and the opinion of the public. The other country's experience proves that it matters which party is in government, who is the president of the central bank and who sits on its board.

The ambivalent position to euro zone joining in the analysed countries can be explained by the interests and policies of certain leading business circles. These interests are fairly unanimous, but they are not without contradictions. For foreign TNCs, the introduction of the Euro is not at all urgent as large part of their transactions is already conducted in Euro. "The Skoda Auto, the Czech car company that is owned by Volkswagen Group, deals mainly in euros" (Prague Post, 16 August 2014). The existence of national exchange rate gives them better opportunity for manipulation with transfer prices and tax evasion. They are better positioned in speculation on financial markets, which can far compensate for losses in transaction costs. The domestic exporting firms are the most ferment proponents, particularly in the Czech Republic and Poland, while some others, often influential, are counter-interested. These are those who face direct competition from foreign investors and rivals, and dependent on imports and EU transfers. Some fear that by giving up the national currency, the 
dominance of foreign TNCs could further increase. As many of them have a low level of transnationalisation, the possible savings in transaction costs do not matter too much for them. Devaluation may offer transitory improvements in their short-term competitive positions, and through it in their trade and financial (speculative) affairs they may realise even extra-profits in the short run. Through devaluation, the revenues from abroad (from off-shore businesses or EU structural and CAP transfers) could be up valued. The aspects of tax evasion also apply in these spheres. The interest and views of trade unions are also contradictory.

When analysing euro adoption prospects, the state of euroisation of the country should be taken into consideration. Euroisation, similarly to dollarization, means a special dual (or parallel) currency system, where besides the national currency the euro is in broad use in the monetary circulation. As the exchanges through the transnational networks affect a large part of GDP of these countries, these transactions mean a certain sort of creeping euroisation of these countries. The free movements of capital, which is legal, already covers a substantial amount of exchanges. In addition, we should mention those payments in hotels, supermarkets or other places, which are conducted in euro in all the countries. The role of this creeping euroisation has dual purpose. It can bring full introduction of the euro closer, but it can delay it as well as it already saves transaction costs.

The level of euroisation would need surveys and research concerning each country. Due to traditional links among the euro candidates, probably the most euroised country is Croatia. Many Croatian small enterprises denominate their debts in euro, and most of the real estate, motor vehicle or accommodation prices are quoted in euro. The euro is broadly used by the population for saving and informal transfers. From the former Yugoslavia, Kosovo and Montenegro unilaterally adopted the euro since 2002.

The role of the media in the process is highly controversial. In Poland, "the media is also not very interested in the euro accession process. Attention on this issue picks up when something happens with exchange rate of the zloty or the euro. Otherwise the euro accession policy is not attracting very much attention." (Verdun 2010: 35) The same applies to the Czech Republic and Hungary. The media follows the euro exchange rate fluctuation, but otherwise is not interested in the question. In one sense, we can state that there is no media for euro in these countries, promoting a real and professional discussion about the pros and cons. As politicians are afraid of loosing votes, they refrain from even mentioning the issue, particularly during the election campaign (see Verdun 2010's reference to the Czech elections in October 2009). In reality, reporting only about the problems caused by the crisis means practically a continuous negative campaign, and the public gets only negative information. In the countries where the euro has been already introduced and the public has direct experience, the opinions are, in fact, overwhelmingly positive. The rejection of the euro often meant no more that "citizens have not felt the euro adaptation issue to be all that important." (Dandashly and Verdun 2009: 10)

Analyses of costs and benefits of euro use brought contradictory results, they do not give any clear cut and overwhelming arguments either pro or con in the discussion about the introduction of the single currency. Definitely, these arguments are not strong enough to influence the attitudes of politicians or the public into either directions. This does not mean that it is not important to create a real and objective media presentation on the issue, because the present negative campaigns can make great damage and divert the debate dealing with the issue according to its merits.

Expert discussion can play important role. One can note that as far as the Hungarian experts of the euro issue are concerned, they are overwhelmingly in favour of joining the euro-zone, while in Poland and Czech Republic the expert elites are more divided (see Palankai 2006). 
Cultural or emotional factors can also be important. They can be attached to anxiety about national independence, identity or sovereignty or to devotion to symbols, like the strong national currency. "To some extent symbolic factors play a role. Euro is a strong symbol of European integration; a national currency is a strong symbol of national identification." (Verdun 2010: 27-28). In Poland and Czech Republic the arguments against the euro often referred to the strong zloty and koruna as a symbol of country success and strength. "Poland's reform, economic growth, its stable economy (compared to other EU countries such as Hungary) even after the crisis were not enough to get closer to euro adoption" (Dandashly 2012: 234).

For the sake of euro adoption several legal problems should be solved. As far as the disputes over compliance with the requirements of central bank independence are concerned, they have been solved, or in case, remaining problems can be easily dealt with. The need for changing constitutions is a more formidable problem, and as among others both the Polish and the Hungarian constitution pledges to present national currency, this can not be avoided. It assumes in both country a two third majority decision of parliament, and this is hardly possible without the consensus of the major political parties.

The joining of the euro zone may raise several sovereignty and security questions, and such related considerations can play an important role. It has a different aspect in different countries, and can influence the politics or public opinion concerning the mere question of joining or its timing. In case of Poland, it is seemingly important both from the point of view of its EU position and security of the country. The security considerations were particularly strengthened by the recent confrontation between the West and Russia. "The new appetite for potential accession to the 18-members euro zone appeared to be a reaction to Russia's annexation in March of territories in Poland's neighbour Ukraine" (Reuters, 4 June 2014). "Entering the euro-zone would be, in a strategic take, another anchor that would maintain Poland in the group of the most important Western nations and increase our security" "Poland will join the euro in the future because adoption of Europe's common currency would raise its status among the Western nations." (Reuters, 9 April 2014.) According to Donald Tusk, the euro joining "is also a geopolitical project."

Similar considerations motivated the Baltic countries. In light of a growing Russian threat, they strived to connect themselves to the West more closely. For Slovakia, the extension of its sovereignty played a role, particularly in terms of getting direct participation in decisions. One thing is, however, clear: except extraordinary circumstances, with great probability, none would join the euro zone until the crisis is over. As Marek Belka, President of the Polish Central Bank stated in 2015: "You shouldn't rush when there is still smoke coming out from a house that was burning. It is simply not safe to do so. As long as the euro zone has problems with some of its members, don't expect us to be enthusiastic about joining."

In fact, the story of Greece is not yet finished, and Grexit cannot be excluded. The discussion of euro adoption in 2014, in both the Czech Republic and Poland were taken off the agenda, seemingly due to the Greek and migration crises. There is a wait and see policy and there are no new developments on the horizon, which can easily change this picture.

What is needed, it is more than over-coming the present crisis. As the defects of the euro have become apparent, it is hard to expect many of the candidates to take it, before these defects are repaired.

\section{References}

Integration Secretariat of Foreign Ministry of Hungary (1997): Agenda 2000. The opinion of European Commission on Hungary's Application to EU Membership. Budapest: Ministry of Foreign Affairs 
Czech National Bank (2011): Analyses of the Czech Republic's Current Economic Alignment with the Euro Area. Prague: CNB.

Dandashly, A. - Verdun, A. (2009): The Domestic Politics of Euro Adaptation in the Czech Republic, Hungary and Poland. Paper delivered at the 2009 American Political Science Association (APSA) Annual Meeting, Toronto, Ontario, Canada. September 3-6.

Dandashly, A. (2012): Domestic politics Comes First - Euro Adoption Strategies in Central Europe: The Cases of Czech Republic, Hungary and Poland. PhD dissertation, submitted to the Department of Political Sciences, University of Victoria.

Eurobarometer (2015): Introduction of the Euro in the Member States that have not yet Adopted the Common Currency. Flash Eurobarometer 418.

ECB (2004): Convergence Report 2004. Frankfurt: European Central Bank

ECB (2010): Convergence Report 2010. Frankfurt: European Central Bank

European Commission (1990): One Market, One Money. European Economy 1990: 17-18.

European Commission. (2008): EMU@: 10Successes and Challenges after 10 Years of Economic and Monetary Union. Brussels: European Commission

European Commission (2014): European Economy. Brussels: European Commission.

European Commission (2015): Eurobarometer Surveys 2015. Brussels: European Commission.

Eurostat (2011): Europe in Figures. Eurostat Yearbook 2009. Brussels: European Commission.

Eurostat (2012): Statistical Books. Brussels: European Commission.

Eurostat (2014): Europe in Figures, Eurostat Yearbook 2014. Brussels: European Commission.

Hungarian National Bank (2001): A forint útja az euróhoz [The Forint's road to the Euro]. Budapest: Hungarian National Bank

Mundell, R. A. (1964): Tariff Preferences and the Terms of Trade. The Manchester School of Economic Studies 32.

Neményi J. (2003) Az euro bevezetésének feltételei Magyarországon [The conditions of introducing the euro in Hungary]. Közgazdasági Szemle 50: 479-504.

Notre Europe (2013): European Public opinion. Facing the Crisis (2007-2013). Policy Paper 90.

OECD (2012): International direct Investment Database. http://www.oecdilibrary.org/finance-and-investment/data/oecd-international-direct-investmentstatistics idi-data-en, accessed 26 September 2016.

Padoa-Schioppa, T. (1989): The EMS: long-term view. CEFR.

Palánkai T. (2004): Economics of Enlarging European Union. Budapest: Akadémia Kiadó.

Palánkai T. (2005): A magyar gazdadaság és társadalom integráció-érettsége, integrációs képessége és felkészültsége címü kutatás: zárótanulmányok. [Integration maturity, integration capacities of Hungarian Economy and Society]. Budapest: Budapesti Corvinus Egyetem. 
Palánkai T., ed. (2006) Európai Unió kapujában: perspektívák és elvárások. Nemzetközi konferencia [At the Gates of the EU: Perspectives and Expectations. International Conference]. Koszeg: ISES.

Benczes, I. - Jensen, J. - Kengyel, Á. - Kutasi, G. - Miklós, G.- Nagy, S. G. - Palánkai T. (eds) (2014): Economics of Global and Regional Integration. Budapest: Akadémiai Kiadó.

Prague Post/The Voice of Prague (2014): The Czechs and the euro.

Prague Post/The Voice of Prague (2014): Euro by 2017?

European Council (1995): Single Market for enlargement. White Paper on the Single Market presented in Cannes, June 1995.

Sobczyk, M. (2012): Euro's Popularity hits Record Low in Poland. The Wall Street Journal

Verdun, A. (2010): Euro Adoption Strategies in Poland. In: Dandashly, A. - Surdej, A. Tendera-Właszczuk, H. (eds) Global Financial Crisis and Euro Zone Enlargement. Toruń: Wydawnictwo Adam Marszałek. 